\title{
Canada's bold experiment with pay equity
}

\author{
Parbudyal Singh and Ping Peng \\ School of Human Resource Management, York University, Toronto, Canada
}

\begin{abstract}
Purpose - The purpose of this paper is to examine the evolution, implementation and effectiveness of the Pay Equity Act in Ontario, Canada. Given that this Act is considered by many as the world's most progressive equal pay for work of equal value legislation, there are important implications for policy globally.

Design/methodology/approach - Through a review of relevant documents and the literature, the paper examines the need for the Pay Equity Act in Ontario, its origins, and with two decades of experience, analyze its effectiveness. A case study is also used to assess related procedures and effects of the law.

Findings - In spite of its limitations and the wide pay gap that still exists between men and women, many female workers have benefited from Ontario's progressive Pay Equity Act. In targeting the discriminatory aspect of women's work evaluations, the Act has resulted in pay increases for thousands of women, especially in the public sector.

Practical implications - There are many practical and social implications for jurisdictions across the globe, as they try to grapple with gender pay equities. Policy makers can learn from the successes and challenges experienced in Ontario. Pay equity legislation will unlikely achieve any significant progress in reducing the wage gap if it relies on workers to complain about the inequity in their pay. A proactive pay equity law, such as that in Ontario, will force employers to make more focused efforts to deal with gender pay discrimination. Ontario's bold "experiment" with pay equity holds valuable lessons for jurisdictions globally.

Originality/value - While there has been some research on the Ontario Pay Equity Act, there is a paucity of scholarly work that examines the details of the pay system that the Act has spawned. There is also little work in assessing the effectiveness of the legislation.
\end{abstract}

Keywords Equal pay, Gender, Discrimination in employment, Women, Labour market, Canada

Paper type General review

\section{Introduction}

While women are making advances in several areas in the labour market, including increased labour force participation rates, there is one area that seems to be stubbornly resisting change: the gender pay gap. While this gap has decreased in some jurisdictions, including Canada and the USA, it still exists globally (Milkovich and Newman, 2008). There are many reasons for the gender pay gap, including occupational segregation and discrimination (Blau and Kahn, 2007). While occupational segregation may be "remedied" through efforts to level the employment playing field, albeit a long and arduous process (e.g. through employment equity legislation), the devaluation of women's jobs through job evaluations and systemic discrimination in the labour market can be addressed much quicker with legislation that seeks to ensure that men and women receive the same pay for work that is of comparable value to the organization.

In 1988, the Ontario Government decided to go this route, with the Pay Equity Act, which sought to address the differential pay by gender for jobs of similar value to the organization; that is, the intent was to make pay comparable for work of equal 
value to the organization. The logical assumption is that once the "discrimination component" of the gender pay gap is addressed, the overall pay gap would be reduced over time. This approach, obviously, would not directly affect the portion of the wage gap that exists for reasons other than discrimination.

Unlike most other pay equity laws that are only complaint-based, the Ontario Pay Equity Act went a step further: it is proactive and covers all employers in the public sector and those in the private sector with more than ten employees (Pay Equity Act, Part I, Section 3). It is proactive in that employers covered under the Act are required to have pay equity strategies in place regardless if there is a complaint or not; employers with 100 or more employees are required to post the plan. In contrast, most jurisdictions in other parts of Canada and elsewhere initiate pay equity only when there is a complaint. The Ontario Pay Equity Act has been described by scholars and practitioners as one of the most comprehensive and progressive pay-equity legislations in the world largely because of its broad coverage and proactive nature (Armstrong and Cornish, 1997; Coutts, 2004; Equal Pay Coalition, 1997b; Gunderson, 1994; McDonald and Thornton, 1998).

Employers in Ontario covered under the Pay Equity Act, both private and public, have since been busy interpreting their obligations and potential liabilities in order to comply with the legislation. Recently, there are questions still being raised. After 20 years of implementation, has it succeeded in achieving its aim to redress systemic gender discrimination in job evaluations and close wage gaps for women working in female-dominated job classes? How effective has this law been in closing the overall gender wage gap? In this paper, we will examine the need for government intervention in the labour market through the Pay Equity Act. We also trace its development and implementation. With two decades of experience, we will attempt to analyze its effectiveness and try to address the questions above. Other legislation affecting pay equity will also be reviewed briefly.

\section{Gender and pay: an overview of the literature on the value of female-dominant work}

During the past 25 years, women have substantially increased their participation in the labour market. For instance, in the USA, the participation rate for women in the labour force reached 61 percent in 2009 (US Bureau of Labor Statistics, 2009). This represents almost 100 percent increase since 1960 when the participation rate was 32 percent (Milkovich and Newman, 2008). Similarly, in Canada, the women's labour force participation rate is now 63 percent (Statistics Canada, 2009). Similar increases have been reported in Europe and elsewhere (International Labour office (ILO), 2007; Warnecke, 2008).

Gilbert (2005) indicated that, in terms of implications for the labour market, the main difference between women in the 1970s and today is that a substantially higher percentage of them are currently receiving degrees in law or medicine, which used to be dominated by men, or other professional graduate education. The increase of degrees awarded to women soared by almost 500 percent in medicine, 800 percent in law and 1,000 percent in business between 1970 and 1997. Moreover, during the past 30 years or so, much of the growth in female labour market representation came from these fields, in spite the fact that one-third of all the women with these degrees chose to stay home to take care of their families (Gilbert, 2005). 
While women are becoming increasingly more important in the labour market, there are numerous barriers and challenges faced. It is not our intent in this paper to theorize on the reasons for these barriers since there is already a voluminous body of research that addresses this issue (Kanter, 1977; Linehan and Scullion, 2008; O'Neil et al., 2008; Powell, 1988; Ragins, 1989; Weyer, 2007). Rather, we focus on what one jurisdiction (Ontario) in Canada is doing to address one aspect of gender labour market inequities, namely, the undervaluing of women's work for compensation purposes.

In Canada, different levels of governments have implemented networks of laws and policies to assist with the improvement of women's status in the workplace. However, statistics demonstrate that women can still be disadvantaged relative to their male counterparts; they are still paid less than men and, in a related phenomenon, are more likely to be segregated into particular industries and occupations (England, 1999; England and Gad, 2002). Despite significant changes in the labour market and in societal attitudes towards women who participate in the paid workforce, a Canadian woman employed full time still makes, on an average, about 70 cents for every dollar that a man earns (Statistics Canada, 2007). In the USA, women earn 75 cents for every dollar earned by their male counterparts (Milkovich and Newman, 2008). In the Nordic countries, the gap is much smaller; women are earning 85 and 90 cents to a dollar of what males make (Cornish and Faraday, 2008).

While the degree/intensity varies around the world, with smaller pay disparities in parts of Europe such as Scandinavia, the undervaluation of women's work is a global phenomenon (Blau and Kahn, 1992; HRSDC, 2001; United Nations, 2009; Yoo, 2003). As Gunderson (1994) argued, both gender wage discrimination and occupational segregation appear to be universal. It is evident that work done primarily by women is not compensated equitably as compared to work done predominantly by men, even after taking into account such factors as years of work experience and occupation (Blau and Kahn, 2007; Drolet, 1999; Moore and Abraham, 2005).

One of the many reasons women are paid less than men can be attributed to the fact that the traditional views of the worth of work historically performed by women still play a role in wage determination. During the nineteenth century, few married women were expected to work outside the home because they were expected to serve as the symbols of their husbands' status (Weiner and Gunderson, 1990; Iyer, 2002; Steinberg, 1990). Their work was limited to such tasks as nursing the sick and teaching in schools. When women gradually replaced men to do the clerical work in the late nineteenth and early twentieth centuries, their pay structure was based on the view that their male family members such as their husbands, fathers and brothers would be their primary financial support instead of their own income. This notion was based on the assumption that men were the main breadwinners and women were only supplementary earners (Iyer, 2002; Steinberg, 1990). This traditional view is rooted so deeply in society that it plays a major role in how we currently evaluate and compensate work, evident when we examine the comparatively low wages paid to employees in jobs traditionally performed by women, such as administrative support positions, librarians, nurses and the like (Weiner and Gunderson, 1990; Steinberg, 1990).

Women-dominated occupations such as nursing, childcare, secretary and librarians have received minimal compensation/job worth attention and tend to be paid poorly as compared to male-dominated job classes such mechanics, truck drivers and shippers (Cortis, 2000). Female-dominated occupations tend to be more service-related and tend 
to involve work which is creative and relational, usually involving intangible aspects such as nurturing, emotion and caring; these jobs tend to be underpaid as compared to male-dominated jobs such as mechanics and general hands - jobs usually requiring more tangible physical demand. The invisibility of the female-dominant work also contributes to the indirect discrimination in setting the values and wages of these jobs (Cortis, 2000; England, 1999). Studies show that society and employers have ignored and undervalued the characteristics associated with women's work and this undervaluing has created huge barriers to women's progression to positions of power in the workplace (Weyer, 2007).

As in many other developed countries, Canada treats the gender pay gap partly as a result of gender discrimination and has implemented different laws and policies at all government levels to redress this discrimination. The pay equity/comparable worth movement in the 1980s in the USA and Canada revealed unrecognized gender discrimination even though they are still at a long distance from achieving the intended goal of closing the discriminatory portion of the gender wage gap (Cortis, 2000). This movement was described by Steinberg (1990, p. 453) as having:

[...] created a framework within which previously invisible or unacknowledged skills associated with historically female and minority work were made visible and argued to be worthy of compensation. It exposed the gender bias embedded in conventional skill definitions of job complexity and human capital characteristics.

The Ontario Pay Equity Act was passed to help redress this gender bias and compensate women equitably for work of equal value to the organization. More specifically, the Act seeks to redress systemic gender discrimination for work done primarily or traditionally by women. How effective has it been? To address this issue, we will first examine the legislation itself, with comparisons to other legislation that can be used to redress gender discrimination. Second, we discuss the actual procedures involved in, for instance, addressing a pay equity complaint. Third, we discuss the empirical research we conducted, as well as previous studies on the effectiveness of the pay equity in Ontario. In the next section, we discuss the research methods used in tackling these objectives.

\section{Methodology}

In this paper, we use a dual approach in addressing the issues raised in the above section. First, we examine the relevant legislation, archival documents and previous studies. This includes an examination and discussion of the relevant legislation in some detail. The review of studies is not limited to scholarly articles only; it includes reports of studies done by non-profit organizations and advocacy groups. In these studies, we focus on aspects of the reports that comment on the effectiveness of the pay equity experience.

Second, we studied a specific case. Multiple sources of information were utilized in the case: the organization's archival documents such as letters, memoranda and administrative documents, as well as interviews. One of the authors was working for the organization in the case study/organization when this research was conducted and she was given full access to the information needed. The executive directors from three non-profit community service agencies that still have pay equity liabilities were interviewed for approximately an hour each. In order not to restrict the respondents' responses, open-ended questions were used, which included: "What role does government 
funding play in your organization's effort to achieve pay equity?", "What will your organization do when these funds are not forthcoming?", "What is the biggest challenge in implementing the Pay Equity Act?", information collected from these interviews was used to supplement the archival data such as organization records and correspondence.

\section{Findings/results}

The Ontario Pay Equity Act - a closer look

In Canada, there are three types of laws addressing gender issues in compensation: human rights, employment standards and pay equity legislations. The province of Ontario's equal employment regulations were implemented with the intention to reduce and eventually remove barriers to gender equality and equity in employment. Since the early 1970s, several policies and legislation aimed at "equal opportunities" for women have been introduced (England and Gad, 2002).

The three laws in Ontario that provide for equal pay regulations are the equal pay provision in the Employment Standards Act, the Human Rights Code which deals with general discrimination and the Pay Equity Act which deals with pay inequities due to gender discrimination. All of these laws apply to both private and public sectors, except the Pay Equity Act, which applies to the private sector only when the employer has ten or more employees. In the following paragraphs, a brief overview of the three laws' procedures in dealing with pay equity is provided.

Each of the above-mentioned laws in Ontario compares work differently in addressing the issue of fairness in compensation for women. The equal pay for equal work provision under Part XII, Section 42 (1) of the Employment Standards Act looks at rate of pay by comparing substantially the same kind of work, requiring virtually the same skill, responsibility and efforts under similar working conditions in the same establishment. If all these conditions are substantially the same, then employers are required to pay the same rate to both male and female incumbents (Ontario Employment Standards Act, Part XII, Section 42.1).

The initial concept of equal pay was limited to the requirement of equal pay for equal work, which, as noted above, is covered by the Employment Standards Act. Comparisons were allowed only if the work done by the female was equal to the work done by the male, with the work having to be identical in every aspect, without allowance for any small differences in any minor component of the job. The comparisons were also restricted to the same occupation and establishment (Employment Standards Act, Part XII, Section 42.1).

The Ontario Pay Equity Act is more flexible in the sense that it allows comparisons to be across occupations, and in circumstances where there are no male comparisons, to be across employers. The Act requires employers to identify inequities in their pay practices and then develop pay equity strategies to close the gaps (Pay Equity Act, Part II, Section 13.4).

Administered and enforced by the Ontario Human Rights Commission, the Human Rights Code looks at equal treatment with respect to employment with no specific comparison of work. Part I (the Freedom from Discrimination section of the Code) states that every person has a right to equal treatment with respect to employment without discrimination because of race, sex, sexual orientation, age, handicap and a few other factors. The Pay Equity Act, on the other hand, looks at compensation for work by comparing work of equal or comparable value. Determination of value is based on the 
composite of skill, effort, responsibility and conditions under which work is normally performed (Pay Equity Act, Part I, Section 5.1).

All of the above-mentioned laws accept differences in pay but from different perspectives. The exception provision under Part XII, Section 4 (2) of the Employment Standards Act considers some differences in pay acceptable, under these circumstances: seniority system; merit system; quality and quantity of production; and any "factor other than sex" (Ontario Employment Standards Act). The Constructive Discrimination provision under Part II, Section 11 (1) of the Human Rights Code accepts differences caused by special programs designed to assist those in need to achieve equal opportunity or to relieve economic disadvantage; reasonable or bona fide qualification because of the nature of employment (Human Rights Code). Part I, Section 8 (1) of the Pay Equity Act permits differences in pay if they are attributable to factors such as: seniority system, temporary training or development assignment equally available to male and female employees, red circling, merit compensation based on formal performance ratings, skills shortage causing a temporary inflation in compensation, differences resulting from bargaining strength and some casual employment (Pay Equity Act).

Part I, Section 13 (4), of the Pay Equity Act requires employers with pay equity plans to make annual adjustments of at least 1 percent of the previous year's payroll until pay equity is achieved. This does not require a complaint. Specific timetables for achieving pay equity are set out in the Act and apply to all public and private sector employers with ten or more employees. Unlike the Pay Equity Act, under both the Employment Standards Act and the Human Rights Code, no specific adjustments/award is required until a complaint is launched and investigated according to the procedures set out in the legislation.

The Pay Equity Act requires that different jobs be evaluated, and the value of work mostly or traditionally done by women be compared to the value of work mostly and traditionally done by men. An employer could compare the value of the work of a secretary, a traditionally female job, to the value of a janitor, a traditionally male job. If the value to the organization is equal or comparable, the secretary must receive at least the same job rate as the janitor unless the pay gap results from permissible differences, such as merit pay (Pay Equity Act; Pay Equity Commission (PEC), 2000a, b).

In order to assist employers to self-manage the pay equity implementation process, the Ontario Government created the PEC to serve as facilitator and mediator in case of a dispute or complaint. The PEC can also initiate pay equity "audits" of workplaces, as was recently done in several cities and across many sectors in Ontario. The commission is composed of two separate and distinct bodies: the Pay Equity Office (PEO) and the Pay Equity Hearings Tribunal (PEHT). Apart from investigating, mediating and resolving complaints, the PEO also provides information and education programs. It has also produced a wide array of manuals, sample case studies and fact sheets to assist both the employer and the employee to understand and comply with the Pay Equity Act (PEC, 2009).

Apart from the work that was done by the PEO, the PEHT also plays an important role in interpreting the essence of the Pay Equity Act. The PEHT is responsible for adjudicating disputes that arise under the Pay Equity Act and has exclusive jurisdiction to determine all questions of fact or law that arise in any matter before it. The decisions of the tribunal are final and conclusive for all purposes. In making its decisions, the tribunal must consider the specific issues in dispute between the parties in the context of the 
policy objectives of the Pay Equity Act. The Tribunal's proceedings are expected to be less formal, less expensive and more expeditious than court proceedings (Gunderson, 2002; PEC, 2009).

Key features of the pay system from a practical perspective

For practitioners, the key steps in establishing a pay system that conforms to the pay equity legislation are as follows. First, organizations with ten or more employees have to identify male and female job classes. A few of the criteria used to help with this determination include the proportion of women and men in the job classes, which gender has traditionally dominated the job class and who most people associate with the job class (male or female). Job classes form the basis for pay comparisons. Second, employers must select a "gender neutral" job evaluation plan to evaluate jobs in the unit. The system that has generally been adopted in Ontario is the point plan, where the key compensable factors include skills, job responsibility, effort and working conditions. In an effort to reduce/eliminate the discriminatory evaluation of women's work embedded in the job analysis through historical stereotyping and other factors, "gender neutrality" implies that all jobs would be analyzed with an "eye" for such distortions. The PEC has been proactive in advising and helping employers to understand their obligations under the Act with the evaluations (PEC, 2009). In unionized workplaces, separate plans are required for different bargaining units and the union must be involved in the process (Hart, 2002).

Third, once the job evaluations are done, all jobs with the same results must be paid similarly. Also, organizations have to assess the reasons for the differences because, as mentioned earlier, some "permissible" differences are allowed (e.g. seniority, merit pay, etc.). If there are no valid reasons for any pay inequities, the law requires that 1 percent of the previous year's budget be allocated to correcting the gender pay in the job class for employers required to post a pay equity plan. That is, jobs of comparable worth to the organization are to be paid the same. There are three approaches in comparing similar job classes that need elaboration as it shows the challenges pay equity faced/is still facing in Ontario.

Overview of the three job comparison methods

As mentioned above, there are four main criteria used by employers to determine the value of the jobs in order to identify if wage gaps exist in their workplaces:

(1) skill;

(2) effort;

(3) responsibility; and

(4) working conditions.

These criteria are used for job comparisons. Some employers select sub-factors such as duties, service, education and experience (PEC, 2000a; Pay Equity Act).

Under the Pay Equity Act, there are three comparison methods that employers can use to achieve equity in their workplaces. They are the job-to-job comparison method, proportional comparison method and the proxy comparison method. Initially, the job-to-job comparison method was the only method available to achieve pay equity under the notion of equal pay for work of equal value. Owing to the limitation of this method that required female job classes to be compared to male job classes within 
the same establishment, many female workers could not benefit from the original intent of the Pay Equity Act. Gunderson (2002) suggested that in the early years of pay equity implementation in Ontario, 31.5 percent of the organizations in the public sector and 27.5 percent in the private sector made no pay equity adjustment because they could not find male comparator groups. The problem was more obvious for small organizations because it would be harder to find male comparators within the same establishment.

In 1989, one year after the enactment of the Pay Equity Act, the PEC reported a list of shortcomings of the legislation to the government. One of the problems raised was that redressing discrimination could be very limited or even non-existent in establishments where jobs were performed by predominantly female employees. The proxy comparison method was recommended to address this issue. In 1993, the New Democratic Party Government amended the Pay Equity Act to allow the "proportional value" method and implemented the "proxy method of comparison" in the public sector (Pay Equity Act, Part III, 2; PEC, 2009).

The amendments allowed for the inclusion of workers in mostly female workplaces to be covered by the Act. Wages can now be compared using a proxy comparison method that allows establishments with no "male comparators" to compare female job classes to the same female job classes in another public sector establishment that was able to achieve pay equity. This is the "comparing apples and oranges" aspect of the system that some pay equity opponents criticize. If all female job classes could not achieve pay equity with the job-to-job method, then the employer is required to use the proportional value method. If neither of the methods is applicable, the employer is required to notify the Commission by submitting a "Notice of Inability to Achieve Equity". The amendments in 1993 also recognized the inability of community-based organizations to fund pay equity adjustments, and accordingly introduced government funding to assist these establishments to meet their pay equity obligations. Funding was provided for an initial wage increase of 3 percent of payroll, and an additional 1 percent of payroll each year after that until pay equity is achieved. Many female workers in the community-based service agencies benefited from the initial down payment from the government. It was estimated that the addition of the proxy method extended the Act's coverage to 100,000 female workers in the public sector (Equal Pay Coalition, 1997a, 2001).

The NDP lost the 1995 provincial elections, and in 1996, the new Progressive Conservative Party Government passed legislation (Schedule J of the Savings and Restructuring Act) to phase out the proxy method so that it was fully repealed from the Pay Equity Act by January 1,1997. However, a legal challenge was brought against this legislation, and in September of 1997, the court declared that Schedule J had no force and effect and reinstated the proxy method in the Pay Equity Act based on the ground that Schedule J violated ss.15 and 28 of the Charter of Rights and Freedoms (Equal Pay Coalition, 1997a).

When Schedule J of the Savings and Restructuring Act in 1996 phased out the proxy method, it changed and reduced employers' obligations for the period from 1994 to 1996. Many of the employers stopped paying out the legal requirement of 1 percent pay equity obligations to their employees. With the reinstatement of the proxy method, employers were required to re-examine their proxy pay equity plans to determine whether any additional retroactive adjustments were needed for the period from 1994 to 1996 in order 
to meet their legal obligations. For many, that meant a pay equity adjustment of a minimum 3 percent of their total 1993 payroll. The 1993 payroll was used because the Act requires that pay equity liability calculation be based on the previous year's total remuneration (Equal Pay Coalition, 1997a; Pay Equity Act, Part II, Section 13.4a).

All three comparison methods are based on a gender-neutral job evaluation system which has advantages and disadvantages (see Milkovich and Newman, 2008, for a discussion of the pros and cons of the point method). Furthermore, each of the three comparison methods has its benefits and limitations. The most obvious advantage is the consistency of the system. Pay adjustment for each job class is based on total points derived from the job evaluation; dollar values are then assigned to the job based on the points. This value can be applied to a wide range of jobs, including newly created jobs as long as they fall into the same job class. The versatility of the system saves employers time by not having to assess each and every job. The disadvantage can be that the value assigned to each factor is based on judgements of the evaluator, which can make it subjective and biased (Gunderson, 2002). In spite of their limitations, all three methods have been effective in ensuring that work of equal value to the organization, regardless of gender, is paid equally (Equal Pay Coalition, 1997a).

The case study

The organization studied, Etobicoke Services for Seniors (ESS), located in Ontario, is a non-profit community-based charitable organization established in 1984 to provide services for seniors. The mission of ESS is to support seniors in their desire to remain in their homes and community. ESS receives funding from the provincial and municipal governments, grants from foundations, service fees, fundraising and donations; over 85 percent of its funding is provided by the Ontario Provincial Government. During the past 20 years, ESS has grown significantly. Its annual budget grew from $\$ 48,000$ to more than $\$ 3$ million, and the workforce increased from two to 70; over 90 percent of its employees are female with an average age of 46 . All job classes are classified as female and employees are non-unionized. The job-to-job comparison method was the only evaluation method when the Pay Equity Act first came into effect in 1988. Owing to the lack of comparative male job classes within the organization, employees at ESS were not eligible for pay equity adjustments, as were female employees in other female-dominated workplaces.

In 1993, the NDP Government amended the Pay Equity Act to include the proportional and proxy comparison methods. The Ontario Government also committed to fund 3 percent of payroll in the first year. ESS was among the organizations that received funding to fulfill its pay equity obligations in 1994. ESS employees benefited from the amended Pay Equity Act by using the new added proxy comparison method.

After receiving permission from the Ontario PEC confirming its status as a public sector employer and a seeking employer, ESS prepared a Pay Equity Plan. The City of Toronto Homes for the Aged was chosen as the proxy employer and all positions were evaluated by using the gender-neutral job evaluation system, i.e. a comparison was made between the female-dominated job classes at ESS and the female job classes at the proxy organization. As a result, in 1993, employees in all female job classes in ESS received a pay increase of approximately 10 percent, a significant increase across board. The Provincial Government helped to fund this pay equity wage and salary increase. 


\section{An evaluation of Ontario's pay equity experience}

Initially, there were mixed opinions towards pay equity legislation. In summary, proponents argued that equal pay is a right and that women are locked in low-paying, sex-segregated jobs because of discrimination and governments need to introduce new laws to redress it (Edmonds, 1999). On the other hand, opponents argued that demanding equal pay for work of equal value is like "demanding that an ounce of lead and an ounce of gold command the same price simply because they weigh the same" (Gairdner, 2006, p. 1). Has the Act delivered as hoped for by proponents? Did it crash the free labour market as implied by some who opposed it? In short, while it has not delivered as much as was expected, it has certainly made a positive impact in the lives of many working-women. We will first discuss some of the challenges and limitations of the pay equity law and related institutional mechanisms in Ontario, then discuss some of its successes.

\section{Challenges and limitations}

After 20 years since the implementation of the Pay Equity Act, many women workers in Ontario have gained significant pay increases. However, pay inequity still exists. It should be emphasized, however, that while the pay gap is still evident, it was not the aim of the Act to close it; rather, it sought to correct historical undervaluing of work performed by women and to ensure that they receive equal pay for work of equal value. There are numerous factors that affect the gap's continued existence which lie outside the law's ambit (Milkovich and Newman, 2008). Nevertheless, the Act has contributed to narrowing the gap, where it was caused by gender discrimination, especially in the public sector (Peng and Singh, 2009).

When the Ontario Government enacted the Pay Equity Act in 1988, the pay gap was at 38 percent. Two decades after the Act's inception, the gap has decreased to 29 percent, which still remains wide (Cornish and Faraday, 2008). Nation-wide, according to Statistics Canada (2007), the national average earning gap appears to be resisting change. In 1998 , full-year, full-time average earning for men was $\$ 55,000$, and $\$ 39,500$ for women; that is, women earned $\$ 0.719$ for every dollar that their male counterparts earned. In 2007, annual earnings for men averaged $\$ 60,300$, while earnings for women averaged at $\$ 43,000$; thus, the gap remained largely the same with women earning $\$ 0.714$ for every dollar their male counters earned. The graph below, based on data from Statistics Canada (2007), illustrates the average earnings for men and women from 1998 to 2007. Obviously, wage inequality continues to persist between men and women workers (Figure 1).

While it has contributed to correcting historical undervaluing of work performed by women, the Pay Equity Act has also created financial dilemmas for many non-profit organizations where the majority of the workforce is female. For example, as we found in the case study, on one hand, the Ministry of Labour that implements the Pay Equity Act requires all employers to fulfill their legal obligation by paying their pay equity liabilities until equity is achieved; on the other hand, the funding ministries, such as the Ministry of Health, decided to stop funding a few times until ordered to resume their funding obligations. The government has once again stopped its designated pay equity funding (since 2005), leaving the burden on those organizations where pay equity has not been achieved and where government funding is crucial for the existence of their services. 
Figure 1.

Full year, full time earnings by sex

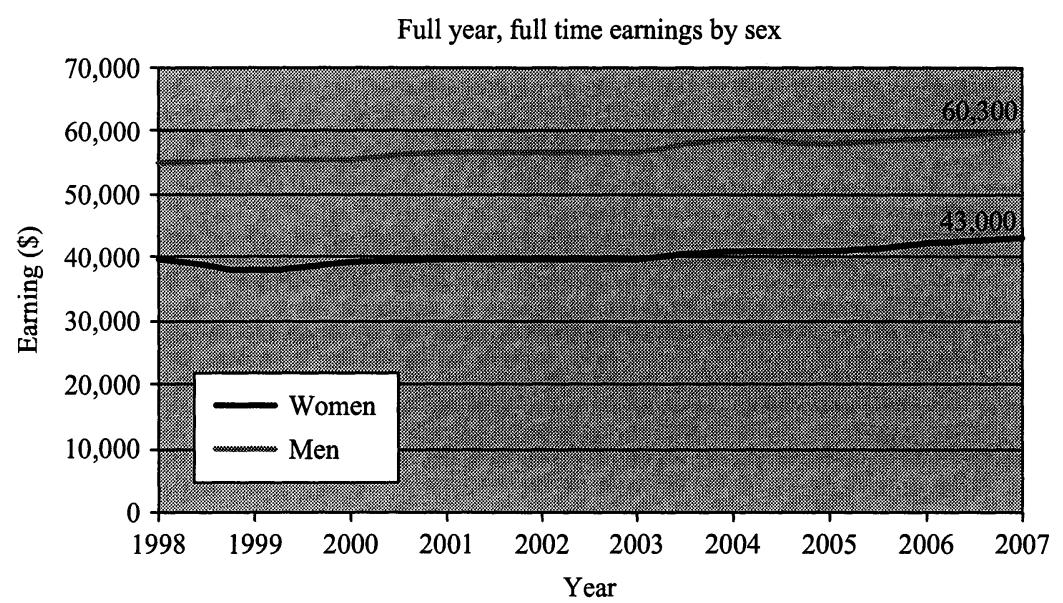

Furthermore, England and Gad (2002) contend that only limited success has been achieved in work place equity after many years of pay equity and employment legislation and that it is entirely possible that the direct and specific impacts of the legislation are limited. This is especially pertinent to the private sector. One of the key reasons for this is not the Act itself but its implementation. That is, there is evidence of non-compliance among employers (McDonald and Thornton, 1998; Equal Pay Coalition, 2001; Baker and Fortin, 2004). For instance, McDonald and Thornton (1998), in a survey of 27 private-sector firms in the Toronto on their experiences with pay equity, found non-compliance or manipulation in ten out of the 27 cases. The researchers reported that several of these non-compliance issues stemmed from ignorance or misunderstanding, while for other firms it was intentional. The Equal Pay Coalition (2001) has also reported on non-compliance, especially among smaller employers. They advocate that there is a need to educate the pubic about pay equity and provide employers with the specialized guidance needed to comply with their legal obligations (the PEC has since made progress on this front, especially with the recent production of an interactive $\mathrm{CD}$ that helps organizations through their job evaluations, etc.). Similarly, Baker and Fortin (2004) reported that there is nearly complete non-compliance among the smallest firms because they lack sufficient resources to conduct proper job evaluations and establish comprehensive job classifications systems; further, they do not have sufficiently large samples sizes of male and female jobs to make decent comparisons. The bottom line from the foregoing is that, while the law exists, it has not been universally applied within the province's workplaces. One of the key reasons for this is that the PEC is not adequately resourced; there have been staff cuts as a result of budgetary constraints over the years, and its library, among other areas, continues to be under-resourced[1].

The administrative costs (costs associated with implementing the process required by the Pay Equity Act) and substantive costs (the amount of pay adjustments) of the legislation also pose a burden on organizations (Iyer, 2002). McDonald and Thornton (1998) reported that 58 percent of the firms they surveyed found pay equity to be a significant administrative burden, including indirect costs such as time away from jobs to work on the pay equity plans. They also reported that the cost of implementing 
pay equity in the public sector was approximately $\$ 173$ per employee, while in the private sector it ranged from approximately $\$ 88$ to $\$ 168$ per employee. It must be noted, however, that these costs are associated with all laws, and that they are "necessary burdens" in tackling gender pay discrimination. In fact, many labour law scholars have argued that labour law should be seen as a way of addressing market failures and promoting equity (Davidov, 2007; Langille, 2006). As Hyde (2006, p. 58) asserts, "there is no theoretical reason for labour law to restrict itself to facilitating efficiency".

Another challenge posed by the Ontario Pay Equity Act is the obligation to maintain pay equity once it has been achieved. For example, any changes to the compensation of employees that may have an effect on the pay equity job rate, such as the introduction of job classes not previously evaluated, must be factored into the comparison of jobs (Kay, 2005). Employers must ensure that they maintain pay equity within the organization by adjusting compensation and benefit packages. All changes in jobs need to be accounted for; however, the complexity of the pay equity process and any absence of active management monitoring systems, make it difficult to maintain. Nevertheless, pay equity was not meant to be a one-time effort and organizations need to actively monitor and maintain it through effective compensation and management practices.

\section{Successes and benefits}

In spite of its limitations and the fact that a pay gap still exists, many female workers have benefited from Ontario's progressive pay equity legislation. To mark the 20th anniversary of the Ontario Pay Equity Act, the Pay Equity Coalition of Ontario, an independent advocacy group, cited the following examples of the inequities which were identified after the introduction of the Act and the pay equity adjustments which were won: secondary school secretaries received an annual increase of $\$ 7,680$ based on their comparison with a male job class of audio-visual technicians; female health technicians were compared to male transportation workers, leading to an increase of $\$ 2.79$ an hour; female-dominated mental health workers were compared to the male personnel officer's job, resulting in a pay equity raise of $\$ 2.20$ per hour; female-dominated police dispatchers were compared to the radio technical supervisors and received an increase of $\$ 7,179.00$ annually; a female job class of law clerk was compared to the male job class of investigator, resulting in a $\$ 4.28$ per hour adjustment; at a baked-goods manufacturer, the female job class of personnel manager was compared to the male job class of service manager, resulting in an adjustment of $\$ 4.65$ per hour (Pay Equity Coalition of Ontario, 2009). Furthermore, in the ESS case study, we found that the legislation certainly helped in improving wages and salaries for women at this particular service sector organization. In this case, women benefited especially from the proxy job evaluation comparison method.

Many female workers would not have been able to obtain such increases in their salaries without the implementation of the Pay Equity Act, which was enhanced by the addition of the proxy method to benefit those women whose workplaces have no male comparators. The adjustments awarded to these female workers made it possible for them to improve the quality of life for themselves and their families. As one leading advocacy group concluded, "No other single law in Canada has resulted in such concrete results for so many working women right where it counts - in their pay cheques and benefits". 


\section{Conclusions}

Ontario's efforts to address the gender pay inequities inherent in job evaluations and the systemic undervaluation of women's work has experienced mixed fortunes. While it has benefited many female workers in that province, there is still an unfulfilled potential. The problem is not so much with the legislation per se; in fact, the Act may be one of the most progressive globally (Armstrong and Cornish, 1997; Coutts, 2004; Gunderson, 1994; McDonald and Thornton, 1998). Rather, the pressing issues relate to its implementation. To address these, there is an immediate need for the government to adequately fund the $\mathrm{PEO}$. There is a need for more officers and funds to train them. Given the proactive nature of the legislation, this would allow the PEO to widen and deepen their audits, including the problematic small business sector (ten to 100 employees). More funds would also help the PEO to develop resources, such as the recent $\mathrm{CD}$, that will help business owners and managers in preparing pay equity plans. Additional resources for the library would serve a valuable educational purpose for all stakeholders.

As argued above, some women have greatly benefited from the Ontario Pay Equity Act, particularly those in the public sector and in larger organizations within the private sector. Yet, inequities exist. However, pay equity and employment equity policies alone cannot significantly improve women's pay as other factors outside the legislative process, such as limited access to training and development, also play important roles. Limits to these opportunities will inevitably affect women's potential for promotions and wage increases. An accommodating workplace without systemic discrimination combined with a supportive environment and better access to training and development opportunities will certainly be beneficial for female workers who must balance work and life at home. In order to promote equitable workplaces, governments must seriously address such issues as family and parental leave, along with quality and accessible child-care.

Future research needs to take a wider perspective on the pay equity/gender pay gap issue. For instance, scholars need to assess the effects of broad societal factors, such as state provision and/or subsidization of child-care on the pay gap. Are there differences in the pay gap between countries that adequately provide for a safe and good learning environment for children versus those that do not? Furthermore, do national cultures influence the pay gap? For instance, would countries rated higher on Hofstede's masculinity and power distance indices have differences in the pay gap versus countries that are rated lower? In Ontario, there is a need for researchers to empirically analyze the data collected by the PEO on cases investigated. A longitudinal analysis of the data would be especially helpful.

Pay equity legislation will unlikely achieve any significant progress in reducing the wage gap, or correcting discrimination in evaluating women's work, if the legislation relies on workers to take the initiative and complain about the inequity in their pay. A proactive pay equity law, such as Ontario's Pay Equity Act, will force employers to fulfill their pay equity obligations, making it possible for tens and thousands of female workers to benefit from the legislation (Equal Pay Coalition, 2009). We humbly suggest that the bold "experiment" in Ontario holds valuable lessons for jurisdictions globally.

Note

1. One of the authors has worked closely with the PEO on several issues; thus, this is first-hand observation. 


\section{References}

Armstrong, P. and Cornish, M. (1997), "Restructuring pay equity for a restructured workforce", Gender, Work and Organizations, Vol. 4 No. 2, pp. 67-86.

Baker, M. and Fortin, N. (2004), "Comparable worth in a decentralized labour market: the case of Ontario", Canadian Journal of Economics, Vol. 27 No. 4, pp. 851-78.

Blau, F. and Kahn, L. (1992), "The gender earnings gap: learning from international comparisons", American Economic Review, Vol. 82, pp. 533-8.

Blau, F. and Kahn, L. (2007), "The gender pay gap: have women gone as far as they can?", Academy of Management Perspectives, February, pp. 7-23.

Cornish, M. and Faraday, F. (2009), "A framework for action on pay equity in Ontario", available at: www.equalpaycoalition.org/cms/upload/EPC_Framework_For_Action_Index_Updated_ April7_09.pdf (accessed September 6 2009).

Cortis, N. (2000), "Gender, pay equity and human service work: a New South Wales case study", Australia Journal of Political Science, Vol. 35 No. 1, pp. 49-62.

Coutts, J. (2004), “Will pay equity close the 'pay gap' between men and women?", New Zealand Roundtable, Policy Backgrounder, February, pp. 1-7.

Davidov, G. (2007), "The (changing?) idea of labour law”, International Labour Review, Vol. 146 Nos 3/4, pp. 311-20.

Drolet, M. (1999), The Persistent Gap: New Evidence on the Canadian Gender Wage Gap, Business and Labour Market Analysis Division-Statistics Canada, Ottawa.

Edmonds, P. (2009), "The wage gap: pay equity debate creates huge political divide", available at: www.fact.on.ca/newpaper/wm990630.htm (accessed November 12009 ).

England, K. and Gad, G. (2002), "Social policy at work? Equality and equity in women's paid employment in Canada", GeoJournal, Vol. 56 No. 4, pp. 281-94.

England, P. (1999), "The case for comparable worth", The Quarterly Review of Economics and Finance, Vol. 39, pp. 743-55.

Equal Pay Coalition (1997a), "September 1997 decision of the Ontario Court of Justice", available at: www.web.net/ equalpay/sept971.html (accessed June 2009).

Equal Pay Coalition (1997b), "The Ontario pay equity experience", available at: www.web.net/ $\sim$ equalpay/experien.html (accessed September 2009).

Equal Pay Coalition (2001), "Proxy pay equity - backgrounder", available at: www.web.net/ $\sim$ equalpay/lobby_backgrounder.html (accessed December 2005).

Equal Pay Coalition (2009), "Ontario 20th anniversary celebration", available at: www. equalpaycoalition.org/anniversary.php (accessed September 6, 2009).

Gairdner, W. (2006), "The pay equity scam", available at: www.williamgairdner.com/the-payequity-scam/ (accessed June 6, 2006).

Gilbert, N. (2005), “What do women really want?", Public Interest, Vol. 158, pp. 21-39.

Gunderson, M. (1994), "Pay and employment equity in the United States and Canada", International Journal of Manpower, Vol. 15 No. 7, pp. 26-43.

Gunderson, M. (2002), "The evolution and mechanics of pay equity in Ontario", Canadian Public Policy, Vol. 28, pp. S118-31.

Hart, S. (2002), "Unions and pay equity bargaining in Canada", Industrial Relations, Vol. 57 No. 4, pp. 609-27.

HRSDC (2001), "Lessons learned gender equality in the labour market", available at: www11.hrsdc. gc.ca/en/cs/sp/hrsdc/edd/reports/2001-002501/page00.shtml (accessed June 2006). 
Hyde, A. (2006), "What is labour law?", in Davidov, G. and Langille, B. (Eds), Boundaries and Frontiers of Labour Law, Hart, Oxford, pp. 37-61.

International Labour Office (ILO) (2007), Key Indicators of the Labour Market, ILO, Geneva.

Iyer, N. (2002), "Working through the wage gap", Report of the Task Force on Pay Equity, Sumach Press, Toronto, pp. 1-154.

Kanter, R. (1977), Men and Women of the Corporation, Basic Books, New York, NY.

Kay, C. (2005), "Pay equity: the unfunded liability", Education Today, Vol. 17 No. 3, p. 6.

Langille, B. (2006), "Labour law's back pages", in Davidov, G. and Langille, B. (Eds), Boundaries and Frontiers of Labour Law, Hart, Oxford, pp. 13-36.

McDonald, J.A. and Thornton, R.J. (1998), "Private-sector experience with pay equity in Ontario", Canadian Public Policy, Vol. 24 No. 2, pp. 185-208.

Milkovich, G. and Newman, J. (2008), Compensation, 9th ed., McGraw-Hill/Irwin, New York, NY.

Moore, M.V. and Abraham, Y.T. (1995), "Comparable worth: is it a moot issue? Controversy, implications, and measurement", Public Personnel Management, Vol. 24 No. 3, pp. 291-314.

O'Neil, D., Hopkins, M. and Bilimoria, D. (2008), "Women's careers at the start of the 21st century: patters and paradoxes", Journal of Business Ethics, Vol. 80, pp. 727-43.

Pay Equity Coalition of Ontario (2009), available at: www.equalpaycoalition.org (accessed October 2009).

PEC (2000a), A Guide to Pay Equity for the Broader Public Sector: A Job Evaluation System, Pay Equity Commission, Toronto.

PEC (2000b), A Guide to the Proxy Comparison Method, Pay Equity Commission, Toronto.

PEC (2009), "Guides and background documents", Pay Equity Commission, www.gov.on.ca/lab/ pec (accessed August 2006).

Peng, P. and Singh, P. (2009), "Pay equity in Ontario: the case of a non-profit senior service organization", Canadian Public Administration, Vol. 52 No. 4, pp. 613-30.

Powell, G. (1988), Women and Men in Management, Sage, Newbury Park, CA.

Ragins, B. (1989), "Barriers to mentoring: the female manager's dilemma", Human Relations, Vol. 42 No. 1, pp. 1-22.

Statistics Canada (2007), "Full time, full year earnings for men and women", 1998 to 2007, available at: www.statcan.ca (accessed November, 2009).

Statistics Canada (2009), "Labour force participation rates by sex and age", available at: www40.statcan.ca/101/cst01/labor05-eng.htm (accessed November 28 2009).

Steinberg, R. (1990), "Social construction of skill: gender, power and comparable worth", Work and Occupations, Vol. 17 No. 4, pp. 449-82.

United Nations (2009), Statistics and Indicators on Women and Men, available at: http://unstats.un. org/unsd/demographic/products/indwm/ww2005/tab5g.htm (accessed November 27, 2009).

US Bureau of Labor Statistics (2009), "Labor force characteristics", www.bls.gov/cps/ lfcharacteristics.htm\#laborforce (accessed September 2010).

Warnecke, T. (2008), "Women as wives, mothers or workers: how welfare eligibility requirements influence women's labour force participation rates", Journal of Economic Issues, Vol. 17 No. 4, pp. 981-1004.

Weiner, N. and Gunderson, M. (1990), Pay Equity: Issues, Options and Experiences, Butterworths, Toronto. 
Weyer, B. (2007), "Twenty years later: explaining the persistence of the glass ceiling for women leaders", Women in Management Review, Vol. 22, pp. 482-96.

Yoo, G. (2003), "Women in the workplace: gender and wage differentials", Social Indicators Research, Vol. 62 No. 1, pp. 367-80.

\section{Further reading}

Linehan, M. and Scullion, H. (2000), "The development of female global managers: the role of mentoring and networking", Journal of Business Ethics, Vol. 83, pp. 29-40.

Wood, G. (2008), "Gender stereotypical attitudes: past, present and future influences in women's career advancement”, Equal Opportunities International, Vol. 27 No. 7, pp. 613-28.

\section{Corresponding author}

Parbudyal Singh can be contacted at: singhp@yorku.ca 